\title{
The Effect of Fetal Thyroidectomy on Thyroid Hormone Metabolism in Maternal and Fetal Sheep
}

\author{
A. Erenberg, K. Omori, W. Oh, and D. A. Fisher ${ }^{[17]}$ \\ Department of Pediatrics, Harbor General Hospital, Torrance, California, and the UCLA School of Medicine, Los Angeles, California, USA
}

\section{Extract}

Experiments were conducted to assess the changes in fetal and maternal iodothyronine kinetics in sheep after removal of the fetal thyroid gland early in the 3rd trimester. Uterotomy was performed at 90-125 days of gestational age; the fetal neck was isolated and a thyroidectomy performed. Indwelling exteriorized fetal carotid artery and maternal jugular vein catheters were inserted and dual ${ }^{131} \mathrm{I}$ - and ${ }^{125}$ I-labeled iodothyronine kinetic studies were conducted in the mother and fetus, respectively, at 4-37 days post-thyroidectomy. Serum thyroxine (T4), triodothyronine (T3), and thyroid-stimulating hormone (TSH) concentrations were measured by radioimmunoassay (RIA). Before thyroidectomy the mean fetal serum T4 level was $12.2 \mu \mathrm{g} / 100 \mathrm{ml}$ (nine animals); this value fell to a mean of $1.7 \mu \mathrm{g} / 100 \mathrm{ml}$ 3 days postoperatively and to a mean of $<0.7 \mu \mathrm{g} / 100 \mathrm{ml} \mathrm{5-6}$ days post-thyroidectomy. The mean fetal serum T3 level was $<18 \mathrm{ng} / 100 \mathrm{ml}$ before thyroidectomy and remained unmeasurable throughout the study. The mean maternal serum T4 and T3 concentrations were $8.9 \mathrm{\mu g} / 100 \mathrm{ml}$ and $94 \mathrm{ng} / 100 \mathrm{ml}$ before thyroidectomy and did not change significantly during the study period. Maternal T4 turnover $\left(\mathrm{T} 4_{\mathrm{s}}\right)$ averaged $533 \mu \mathrm{g} / 24 \mathrm{hr}(11.9 \mu \mathrm{g} / \mathrm{kg} / 24 \mathrm{hr})$ after fetal thyroidectomy, whereas the fetal value was $<4.9 \mu \mathrm{g} / 24 \mathrm{hr}(<3.2 \mu \mathrm{g} / \mathrm{kg} / 24 \mathrm{hr})$. Maternal T3 turnover $\left(\mathrm{T}_{\mathrm{s}}\right)$ averaged $62 \mu \mathrm{g} / 24 \mathrm{hr}(1.27 \mu \mathrm{g} / \mathrm{kg} / 24 \mathrm{hr})$ after fetal thyroidectomy; the fetal value was $<2.26 \mu \mathrm{g} / 24 \mathrm{hr}(<1.05 \mu \mathrm{g} / \mathrm{kg} / 24 \mathrm{hr})$. These fetal values, and particularly the the T4 results, are much less than those in the euthyroid fetus $(<1.45$ and $41 \mu \mathrm{g} / \mathrm{kg} / 24$ hr for T3 and T4).

Placental transfer of butanol-extractable $\mathrm{T} 4$ and $\mathrm{T} 3$ radioactivity occurred in both the fetal-maternal (F-M) and maternal-fetal (M-F) directions; chromatographic studies revealed that the transferred radioactivity represented T4 or T3. The mean fractional rate constants for T4 transfer were $0.0009 / \mathrm{hr}^{-1}$ and $0.00003 / \mathrm{hr}^{-1}$ and for T3 transfer, $0.007 / \mathrm{hr}^{-1}$ and $0.002 / \mathrm{hr}^{-1}$ in the F-M and M-F directions. Estimated net transfer of T4 was $0.6 \mu \mathrm{g}$ and of T3, $0.7 \mu \mathrm{g} / 24 \mathrm{hr}$ in the M-F direction. These amounts represent only about $7 \%$ of total T4 equivalent turnover (T4s $+4 \times \mathrm{T} 3 \mathrm{~s})$ in euthyroid fetuses, and the high fetal serum TSH concentrations $(300-1,500 \mu \mathrm{U} / \mathrm{ml})$ indicated that the thyroidectomized fetuses were, in fact, hypothyroid. The present data indicate that fetal thyroidectomy in the sheep results in fetal hypothyroidism which persists in spite of large M-F gradients of T4 and T3 and a large F-M gradient of TSH. The results further substantiate the autonomy of the fetal pituitary-thyroid sys- 
tem; TSH and thyroid hormones do not cross the placenta in significant quantities even after fetal thyroidectomy.

\section{Speculation}

The present results suggest that the athyroid fetus probably develops in utero in the absence of significant quanities of thyroid hormones. The fact that growth retardation is not observed at birth in the athyroid human fetus suggests that fetal somatic growth may not be thyroid hormone dependent. The high rate of $\mathrm{T} 4_{\mathrm{s}}$ in the euthyroid fetus may be important to development of fetal brain and of bone near term.

\section{Introduction}

We reported studies previously of thyroid hormone kinetics and placental iodothyronine transfer in maternal and euthyroid fetal sheep during the 3rd trimester of pregnancy [3-5]. The results of these studies indicated that the ovine fetal pituitary-thyroid axis is autonomous and that ovine fetal T4 turnover exceeds maternal turnover by a factor of 6-8. The experiments in the present report were conducted to assess the changes in fetal and maternal iodothyronine kinetics in the sheep when the fetal thyroid gland is removed early in the 3rd trimester.

\section{Methods and Materials}

Seven 1-4-year-old Columbia and/or Columbia Suffolk date-bred ewes were obtained from a local source, maintained at environmental temperatures of $50-82^{\circ} \mathrm{F}$, and given free access to alfalfa and water. Under spinal anesthesia, a uterotomy was performed at 90-125 days gestation. The fetal neck was isolated, exposed, and a thyroidectomy performed. In four animals (sheep 2, 4, 21, and 22), indwelling, exteriorized fetal carotid artery and maternal jugular vein cathe-

Table I. Age and weight of animals used in the thyroxine kinetic studies

\begin{tabular}{|c|c|c|c|c|}
\hline \multirow{2}{*}{ Sheep } & \multirow{2}{*}{$\begin{array}{c}\text { Estimated } \\
\text { gestational } \\
\text { age at } \\
\text { thyroidectomy, } \\
\text { days }\end{array}$} & \multirow{2}{*}{$\begin{array}{l}\text { Estimated } \\
\text { gestational } \\
\text { age when } \\
\text { study } \\
\text { performed, days }\end{array}$} & \multicolumn{2}{|c|}{ Weight, kg } \\
\hline & & & Maternal & Fetal \\
\hline 2 & 105 & 109 & 39.5 & 1.010 \\
\hline 4 & 100 & 104 & 39.1 & 1.475 \\
\hline 14 & 97 & 124 & 53.2 & 1.530 \\
\hline 19 & 90 & 120 & 47.7 & 1.360 \\
\hline 20 & 95 & 125 & 54.5 & 2.580 \\
\hline Mean & & & 46.8 & 1.711 \\
\hline SEM & & & 3.3 & 0.26 \\
\hline
\end{tabular}

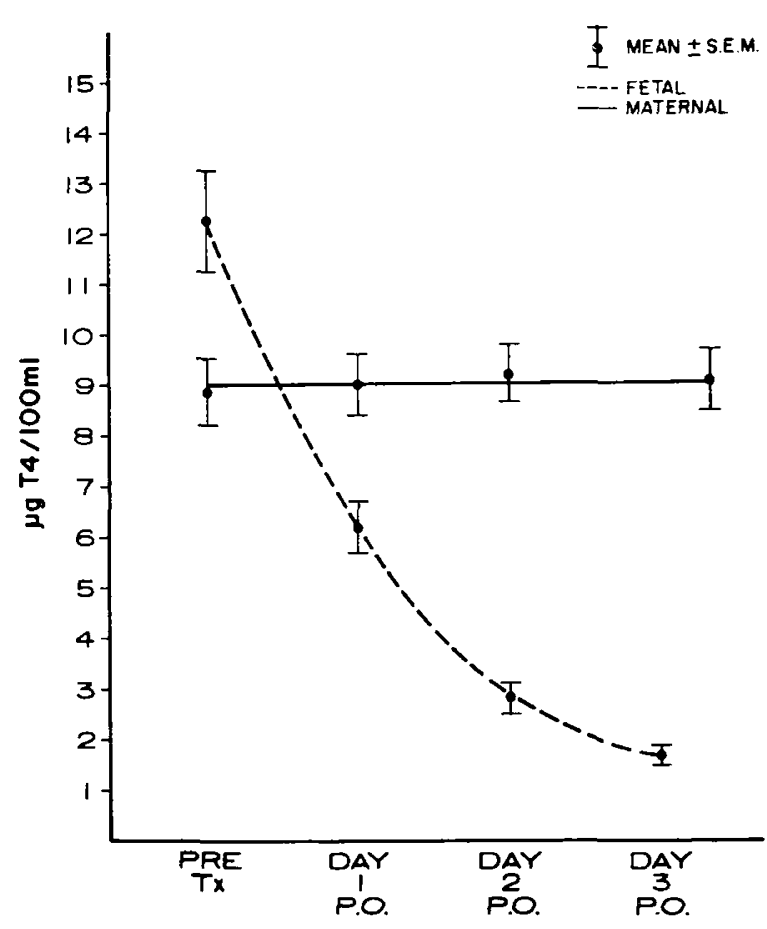

Fig. 1. Disappearance of endogenous plasma serum thyroxine $(T f)$ concentrations after fetal thyroidectomy. Fetal serum thyroxine values fall from a mean of 12.2 to a mean of $1.7 \mu \mathrm{g} / 100 \mathrm{ml}$ within 3 days. P.O.: postoperative.

ters were placed at the time of thyroidectomy. In three animals (sheep 14,19, and 20), a repeat uterotomy was performed 25-27 days post-thyroidectomy, at which time catheters were inserted. Kinetic studies were begun 4-37 days post-thyroidectomy. Five studies were conducted in which tracer doses of ${ }^{125}$ I-labeled T4 $(200$ $\mu \mathrm{Ci}$, spec act $100 \mathrm{mCi} / \mathrm{mg}$ ) and ${ }^{131}$ I-labeled $\mathrm{T} 4$ $(200-450 \mu \mathrm{Ci}$, spec act $90 \mathrm{mCi} / \mathrm{mg})$ were injected into the fetus and mother, respectively (Table $\mathbf{I}$ ). In four studies, ${ }^{125} \mathrm{I}$-labeled T3 $(100 \mu \mathrm{Ci}$, spec act $100 \mathrm{mCi} / \mathrm{mg})$ and ${ }^{131}$ I-labeled T3 $(200-400 \mu \mathrm{Ci}$, spec act $84 \mathrm{mCi} / \mathrm{mg})$ were injected into the fetus and mother, respectively 
(Table III). Two of the T3 kinetic studies were conducted in preparations in which $\mathrm{T} 4$ kinetics had been studied 7 days previously (sheep 90 and 95). During each study serial blood samples were drawn from fetus and mother for a period of up to $72 \mathrm{hr}$. Potassium perchlorate $(400 \mathrm{mg})$ was administered orally to the mother twice daily throughout the study.

Aliquots of the injected radioiodinated iodothyronine were kept in a $1 \%$ albumin solution as reference standards. Alkali-washed butanol extracts of $250-\mu \mathrm{l}$ aliquots of each serum were prepared in duplicate as described by Fisher et al. [8]; 94-99\% of the T3 or T4 radioactivity and $0.2-0.5 \%$ of the inorganic iodine were recovered in the washed butanol extracts. Butanol extracts and standards were counted for ${ }^{125} \mathrm{I}$ and ${ }^{131}$ I activities and butanol-extractable serum radioactivity recorded as a percentage of the injected dose per liter of plasma. Serum butanol-extractable radioactivity was plotted semilogarithmically against time and the final, single exponential disappearance curves were determined by least-squares regression analysis. From these curves, the half-time $\left(\mathrm{t}_{1 / 2}\right)$ of plasma disappear-

Table II. Thyroxine (T4) kinetic data in maternal and thyroidectomized fetal sheep ${ }^{1}$

\begin{tabular}{|c|c|c|c|c|c|c|c|c|c|c|}
\hline \multirow{3}{*}{ Sheep } & \multicolumn{5}{|c|}{ Maternal } & \multicolumn{5}{|c|}{ Fetal } \\
\hline & \multirow[b]{2}{*}{$\underset{\text { liters }}{T 4 V_{D}}$} & \multirow[b]{2}{*}{$\begin{array}{c}T_{4} t_{1 / 2} \\
\text { days }\end{array}$} & \multirow[b]{2}{*}{$\begin{array}{c}\text { Serum } \mathrm{T}_{t} \\
\text { conc., } \\
\mu \mathrm{g} / 100 \mathrm{ml}\end{array}$} & \multicolumn{2}{|c|}{$\mathrm{T} 4_{\mathrm{s}}$} & \multirow[b]{2}{*}{$\underset{\text { liters }}{\mathrm{T} 4 \mathrm{~V}_{\mathrm{D}}}$} & \multirow[b]{2}{*}{$\begin{array}{c}T_{4} t_{1 / 2}, \\
\text { days }\end{array}$} & \multirow[b]{2}{*}{$\begin{array}{c}\text { Serum } T t \\
\text { conc., } \\
\mu \mathrm{g} / 100 \mathrm{ml}\end{array}$} & \multicolumn{2}{|c|}{$\mathrm{T} 4_{s}$} \\
\hline & & & & $\mu \mathrm{g} / 24 \mathrm{hr}$ & $\mu \mathrm{g} / \mathrm{kg} / 2 \mathrm{thr}$ & & & & $\mu \mathrm{g} / 24 \mathrm{hr}$ & $\mu \mathrm{g} / \mathrm{kg} / 24 \mathrm{hr}$ \\
\hline 2 & 11.0 & 1.12 & 8.8 & 600 & 15.2 & 0.74 & 0.83 & $<0.7$ & $<4.87$ & $<4.82$ \\
\hline 4 & 14.3 & 1.38 & 10.0 & 715 & 18.3 & 0.67 & 0.71 & $<0.7$ & $<4.83$ & $<3.28$ \\
\hline 14 & 11.1 & 1.54 & 8.0 & 400 & 7.5 & 1.22 & 0.92 & $<0.7$ & $<6.40$ & $<4.19$ \\
\hline 19 & 14.7 & 1.71 & 7.5 & 452 & 9.5 & 1.09 & 1.33 & $<0.7$ & $<3.97$ & $<2.02$ \\
\hline 20 & 12.0 & 1.33 & 8.0 & 499 & 9.2 & 1.14 & 1.17 & $<0.7$ & $<4.71$ & $<1.82$ \\
\hline Mean & 12.6 & 1.42 & 8.5 & 533 & 11.9 & 0.97 & 0.99 & $<0.7$ & $<4.95$ & $<3.23$ \\
\hline SEM & 0.8 & 0.10 & 0.4 & 56 & 2.1 & 0.11 & 0.11 & & $<0.40$ & $<0.60$ \\
\hline
\end{tabular}

${ }^{1} V_{D}: T 4$ volume of distribution; $t_{1 / 2}:$ plasma half-time of labeled $T 4$ disappearance; $T 4_{\mathrm{S}}:$ daily $\mathrm{T} 4$ turnover.

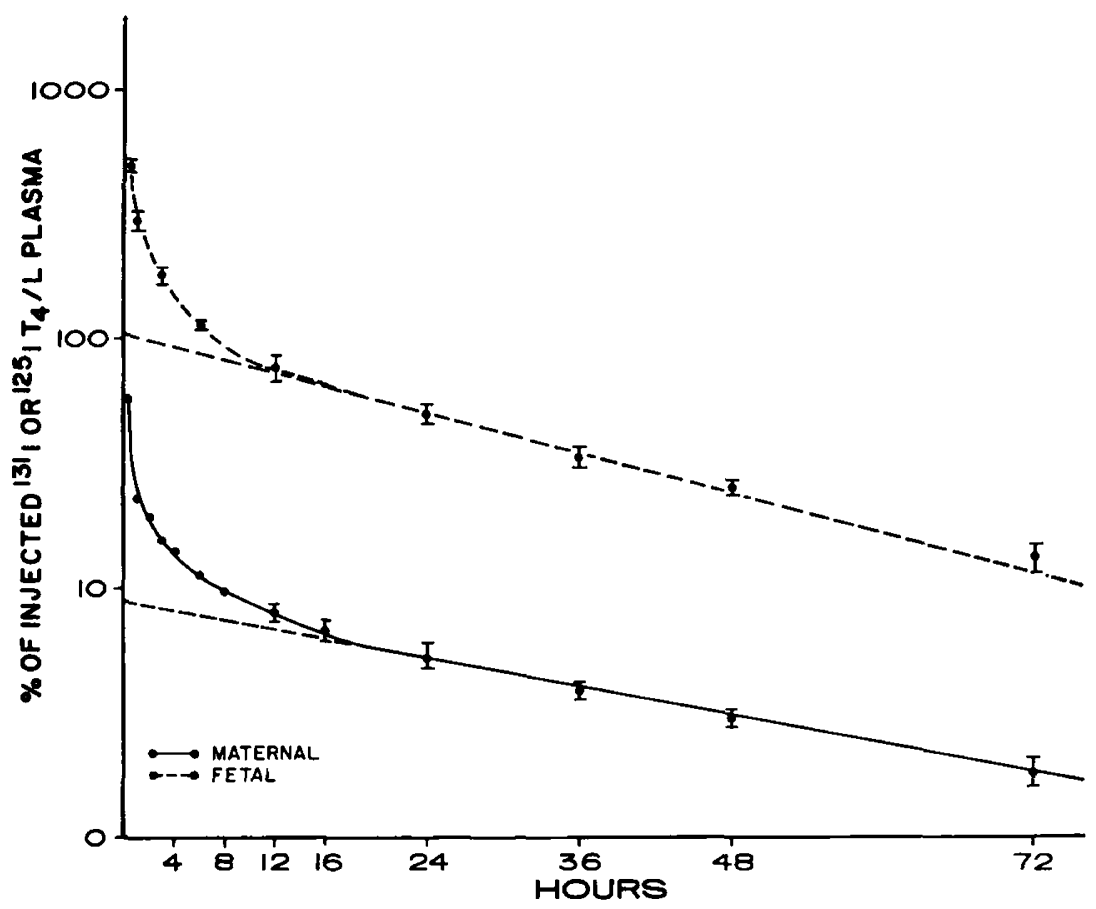

Fig. 2. Labeled thyroxine ( ${ }^{131} I$ or $\left.{ }^{125} I T_{4}\right)$ disappearance in intact maternal and thyroidectomized fetal sheep after separate injections of ${ }^{131 I}$ and ${ }^{126}$ I, respectively. Each point and deviation represents the mean \pm SEM of five animals. 
ance of $\mathrm{T} 3$ and $\mathrm{T} 4$ were determined. $\mathrm{T} 3$ and $\mathrm{T} 4$ distribution volumes $\left(V_{D}\right)$ were estimated by extrapolation of the final single exponential disappearance curves to zero time and calculation of the apparent volume of hormone distribution by a simple dilution formula. Fractional T3 and T4 degradation rates $(\mathrm{k})$ were computed as: $\mathrm{k}=0.693 /\left(\mathrm{t}_{1 / 2}\right)$.

The turnover rates of $\mathrm{T} 3$ and $\mathrm{T} 4$ were calculated as: $\mathrm{T} 3_{\mathrm{S}}$ or $\mathrm{T} 4 \mathrm{~S}(\mu \mathrm{g} / 24 \mathrm{hr})=\operatorname{serum} \mathrm{T} 3$ or $\mathrm{T} 4(\mu \mathrm{g} /$ liter $) \times$ $\mathrm{V}$ (liter) $\times$ k. Serum T4 and T3 concentrations were measured by radioimmunoassay methods developed in our laboratories [1, 2]. Serum TSH was measured using a double antibody, heterologous (bovine) radioimmunoassay system developed in our laboratories. This system is sensitive to about $10 \mu \mathrm{U}$ ovine TSH standard [14 ]. Student's $t$ test was used to assess significance of the differences between euthyroid and hypothyroid data.

Fetal-maternal and maternal-fetal clearances of labeled T3 and T4 were estimated by assuming exchange between two compartments (maternal and fetal) from which irreversible clearance is ongoing simultaneously; these methods have been described previously [4]. To identify the form of radioactivity crossing the placenta, unwashed butanol extracts of serum, supernatant solutions from protein-bound iodine (PBI) precipitates, and dialysates from maternal and fetal sera were chromatographed on Whatman no. 3 paper using butanol-acetic acid (BAA) and tertiary amyl alcohol-ammonia (TAA) solvent systems as described previously [4].

\section{Results}

\section{$T+$}

Maternal and fetal weights and fetal gestational ages at the time of thyroidectomy and at the time of the $\mathrm{T} 4$ kinetic studies are listed in Table I. Before thyroidectomy the mean fetal serum T4 level was $12.2 \mu \mathrm{g} / 100$ $\mathrm{ml}$ (nine animals); this value fell to a mean of 1.7 $\mu \mathrm{g} / 100 \mathrm{ml} 3$ days postoperatively (Fig. 1) and to a mean of $<0.7 \mu \mathrm{g} / 100 \mathrm{ml} \mathrm{5-6}$ days post-thyroidectomy. The mean maternal serum $\mathrm{T} 4$ concentration was 8.9 $\mu \mathrm{g} / 100 \mathrm{ml}$ before thyroidectomy and did not change significantly during the study period. Table II summarizes the $T 4 V_{D}$ and $T 4 t_{1 / 2}$ values, serum $T 4$ concentrations, and calculated $\mathrm{T} 4$ turnover rates for the five maternal-fetal pairs. Composite maternal and fetal T4 disappearance curves are depicted in Figure 2. Mean maternal and fetal T4 distribution volumes were 12.6

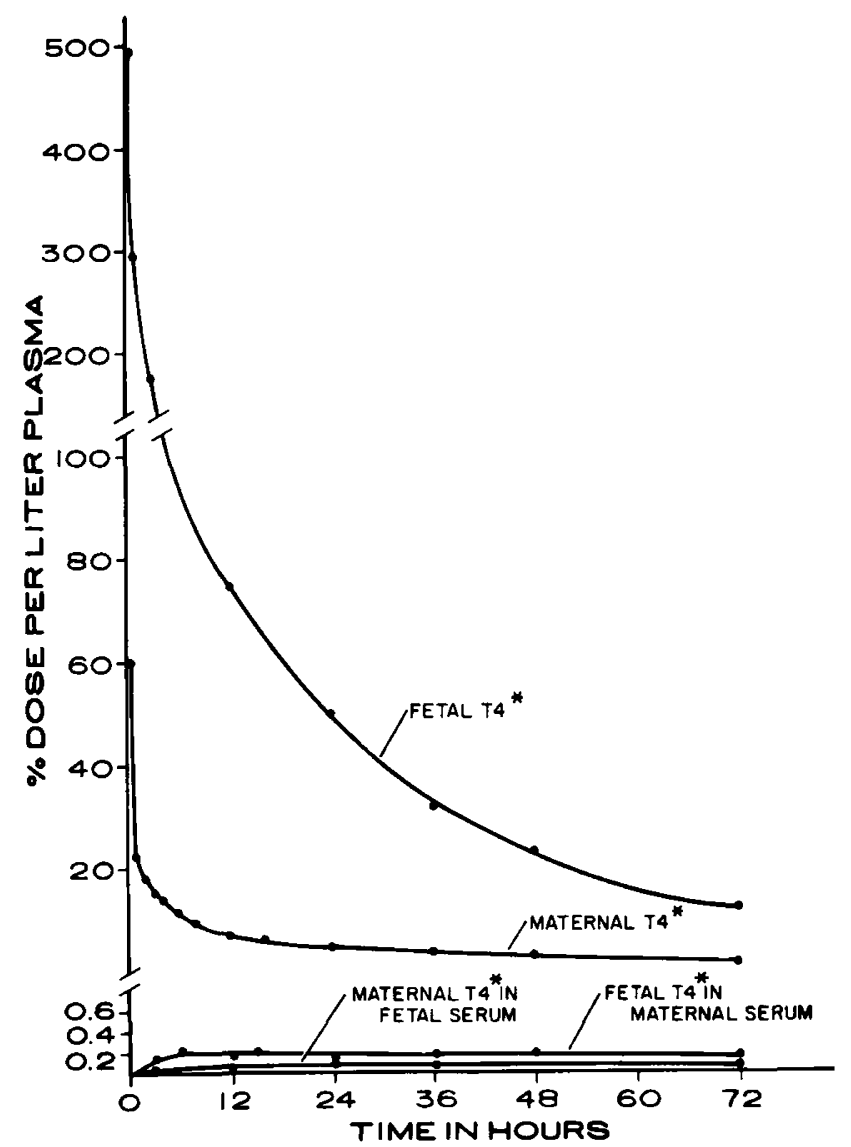

Fig. 3. Arithmetic plots of the disappearance of labeled thyroxine $\left(T 4^{*}\right)$ from fetal and maternal sera and the appearance of fetal-labeled $\mathrm{T}^{*}{ }^{*}$ in maternal serum and maternal-labeled $\mathrm{T} 4^{*}$ in fetal serum. The data represent mean values of all experiments.

and 0.97 liters. Mean \pm sEM extrathyroidal $\mathrm{T} 4$ pool sizes in the mothers and their fetuses (not shown) were $1070 \mu \mathrm{g} \pm 97 \mu \mathrm{g}$ and $<6.8 \mu \mathrm{g} \pm<0.8 \mu \mathrm{g}$; mean $\mathrm{t}_{1 / 2}$ values were 1.42 and 0.99 days. Mean \pm SEM fractional degradation rates [1] for T4 (not shown) were $0.50 \pm$ 0.03 and $0.77 \pm 0.10$ in the mothers and fetuses. Calculated mean maternal and fetal $\mathrm{T} 4$ turnover rates were 11.9 and $<3.2 \mu \mathrm{g} / \mathrm{kg} / 24 \mathrm{hr}$.

Placental transfer of butanol-extractable radioactivity occurred in both directions (Fig. 3). The mean fractional rate of $\mathbf{T} 4$ transfer was greater in the fetal to maternal direction $\left(0.00088 / \mathrm{hr}^{-1}\right.$ versus $0.00003 /$ $\mathrm{hr}^{-1}$ ); the maximum concentration of fetal T4 label in maternal serum at $24-36 \mathrm{hr}$ was twice the maximum concentrations of maternal T4 label in fetal serum. Chromatography of the dialysates of maternal and fetal sera and of PBI supernatants revealed predominantly inorganic iodide, as expected. However, some T4 was identified. By contrast, chromatography of al- 


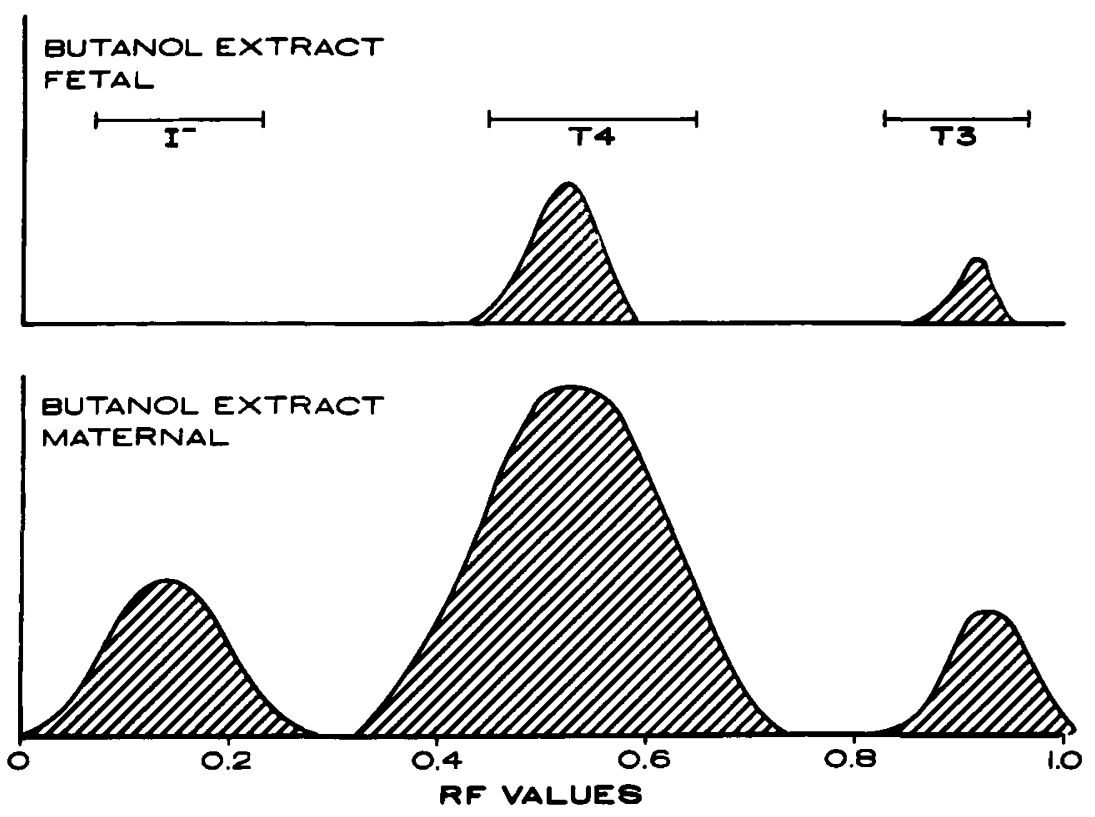

Fig. 4. Drawings of paper chromatographs of unwashed butanol extracts of fetal and maternal sera developed in a tertiary amyl alcohol-2 $\mathrm{N}$ ammonia solvent system. The extracts show predominantly thyroxine (T4) with small amounts of triiodothyronine (T3). Iodide is present in the extracts of maternal sera since these extracts were not washed with alkali.

kali-washed butanol extracts of sera showed predominantly T4, although a small amount of T3 $(<1 \%)$ was separated using the TAA solvent systems. Representative chromatographs are shown in Figure 4.

\section{$T 3$}

Table III lists maternal and fetal weights and fetal gestational ages at the time of thyroidectomy and at the time of isotope study. Table IV summarizes $T 3 V_{D}$ and $T 3 t_{1 / 2}$ values, serum $T 3$ concentrations, and calculated T3 turnover rates for the four maternal-fetal pairs. Composite maternal and fetal T3 disappearance curves are depicted in Figure 5. The mean and SEM maternal serum T3 concentration was $94 \pm 5.3 \mathrm{ng} / 100$

Table III. Age and weight of animals used in the triiodothyronine kinetic studies

\begin{tabular}{lccccc}
\hline Sheep & $\begin{array}{c}\text { Estimated } \\
\text { gestational } \\
\text { age at } \\
\text { thyidectomy, } \\
\text { days }\end{array}$ & $\begin{array}{c}\text { Estimated } \\
\text { gestational age } \\
\text { when study } \\
\text { performed, } \\
\text { days }\end{array}$ & \multicolumn{2}{c}{ Weight, kg } \\
\cline { 5 - 6 } \cline { 4 - 5 } & 90 & 127 & Maternal & Fetal \\
\hline 20 & 95 & 132 & 57.7 & 1.360 \\
21 & 110 & 114 & 50.0 & 2.580 \\
22 & 125 & 129 & 51.8 & 2.570 \\
& & & & 51.0 & 2.202 \\
Mean & & & 1.4 & 0.22 \\
SEM & & & & & \\
\hline
\end{tabular}

$\mathrm{ml}$ before thyroidectomy and did not change significantly during the study period. Before thyroidectomy the mean fetal serum T3 level was $<18 \mathrm{ng} / 100 \mathrm{ml}$, the lower limit of the assay, and remained unmeasurable throughout the study. Mean maternal and fetal T3 $V_{D}$ values were 36.7 and 7.5 liters. The mean \pm sEM extrathyroidal T3 pool sizes in the mothers and fetuses (not shown) were $25.4 \mu \mathrm{g} \pm 5 \mu \mathrm{g}$ and $<1.50 \mu \mathrm{g} \pm 0.22 \mu \mathrm{g}$; mean maternal and fetal T3 $\mathrm{t}_{1 / 2}$ values were 6.7 and $10.0 \mathrm{hr}$. Mean \pm SEM fractional degradation rates $(\mathrm{k})$ of T3 were $2.52 \pm 0.16$ and $1.67 \pm 0.05$ in the mothers and fetuses (not shown). Calculated mean T3 turnover rates were 1.27 and $<1.05 \mu \mathrm{g} / \mathrm{kg} / 24 \mathrm{hr}$ in the mothers and fetuses.

Placental transfer of butanol-extractable $\mathrm{T} 3$ radioactivity occurred in both directions (Fig. 6). The mean fractional rate of T3 transfer was greater in the fetal to maternal direction $\left(0.0068 / \mathrm{hr}^{-1}\right.$ versus $0.0018 /$ $\mathrm{hr}^{-1}$ ); the maximum concentration of fetal T3 label in maternal serum at 1-2-hr was between 2 and 5 times the maximal concentration of maternal $\mathrm{T} 3$ label in fetal serum (at $12 \mathrm{hr}$ ).

Chromatography of butanol extracts revealed that the radioactivity migrated as $\mathrm{T} 3$ in both the BAA and TAA solvent systems. The dialysates of maternal and fetal sera and the PBI supernatants contained predominantly iodide, as in the T4 studies. However, there was also a substance which appeared in the aqueous 
Table IV. Triiodothyronine (T3) kinetic data in maternal and thyroidectomized fetal sheep ${ }^{1}$

\begin{tabular}{|c|c|c|c|c|c|c|c|c|c|c|}
\hline \multirow{3}{*}{ Sheep } & \multicolumn{5}{|c|}{ Maternal } & \multicolumn{5}{|c|}{ Fetal } \\
\hline & \multirow[b]{2}{*}{$\begin{array}{c}\mathrm{T} 3 \mathrm{~V}_{\mathrm{D}} \text {, } \\
\text { liters }\end{array}$} & \multirow[b]{2}{*}{$\begin{array}{c}\text { T3 } \mathrm{t}_{1 / 2,} \\
\text { days }\end{array}$} & \multirow[b]{2}{*}{$\begin{array}{l}\text { Serum T3 } \\
\text { conc., } \\
\mathrm{ng} / 100 \mathrm{ml}\end{array}$} & \multicolumn{2}{|c|}{ T3s } & \multirow[b]{2}{*}{$\underset{\text { liters }}{\mathrm{T} 3 \mathrm{~V}_{\mathrm{D}}}$} & \multirow[b]{2}{*}{$\begin{array}{c}\text { T3 } t_{1 / 2,} \\
\text { days }\end{array}$} & \multirow[b]{2}{*}{$\begin{array}{l}\text { Serum T3 } \\
\text { conc., } \\
\text { ng/100 ml }\end{array}$} & \multicolumn{2}{|c|}{$\mathrm{T} 3 \mathrm{~s}$} \\
\hline & & & & $\mu \mathrm{g} / 2+\mathrm{hr}$ & $\mu \mathrm{g} / \mathrm{kg} / 24 \mathrm{hr}$ & & & & $\mu \mathrm{g} / 24 \mathrm{hr}$ & $\mu \mathrm{g} / \mathrm{kg} / 24 \mathrm{hr}$ \\
\hline 19 & 19.2 & 5.7 & 100 & 55.4 & 1.16 & 4.8 & 10.5 & $<18$ & $<1.36$ & $<0.70$ \\
\hline 20 & 18.5 & 7.8 & 80 & 31.3 & 0.57 & 7.0 & 10.6 & $<18$ & $<1.99$ & $<0.77$ \\
\hline 21 & 34.5 & 7.0 & 104 & 85.8 & 1.72 & 8.1 & 9.4 & $<18$ & $<2.60$ & $<1.53$ \\
\hline 22 & 34.5 & 6.3 & 92 & 84.4 & 1.63 & 10.0 & 9.6 & $<18$ & $<3.11$ & $<1.21$ \\
\hline Mean & 26.7 & 6.7 & 94 & 62.2 & 1.27 & 7.5 & 10.0 & $<18$ & $<2.26$ & $<1.05$ \\
\hline SEM & 4.5 & 0.5 & 5.3 & 13.0 & 0.26 & 1.1 & 0.3 & & $<0.39$ & $<0.19$ \\
\hline
\end{tabular}

${ }^{1} V_{D}$ : T3 volume of distribution; $t_{1 / 2}$ : plasma half-life of labeled $T 3$ disappearance; $T 3_{B}$ : daily $T 3$ turnover.

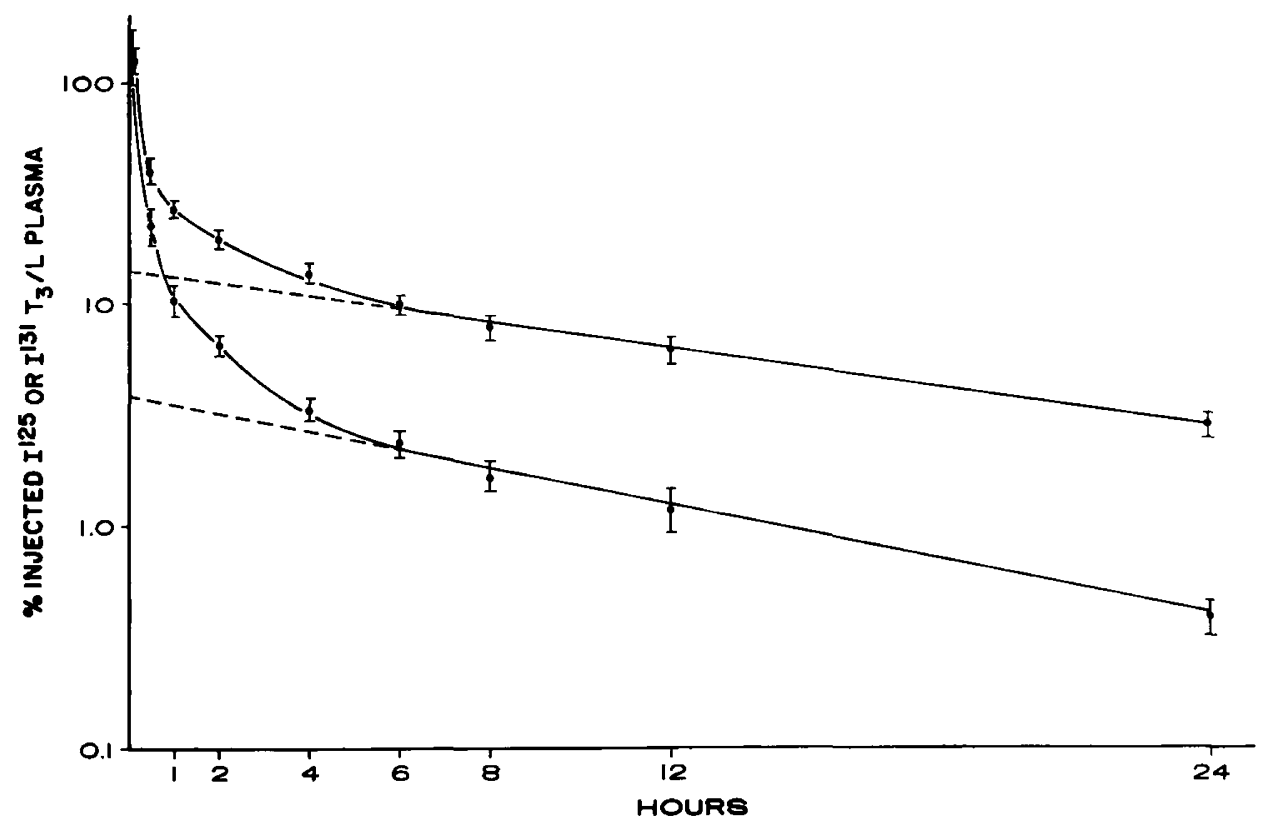

Fig. 5. Labeled triiodothyronine ( $I^{125}$ or $I^{131} T_{3}$ ) disappearance in intact maternal and thyroidectomized fetal sheep. The upper line represents the disappearance of ${ }^{125}$ I- labeled triiodothyronine (T3) from fetal serum, the lower line the disappearance of ${ }^{131}$ I-T3 from maternal serum after separate injections. Each point and deviation represents the mean \pm SEM for four animals.

dialysates of fetal and maternal sera moving just ahead of iodide and not present in the washed butanol extracts. This compound may represent the T3 sulfate conjugate previously identified in fetal and maternal blood of monkeys by Schultz et al. [13] (Fig. 6).

Serum TSH concentrations were measured in three of the five thyroidectomized fetuses in the $\mathrm{T} 4$ studies $(14,19$, and 20 , Table I); the values were 350,720 , and $1,500 \mu \mathrm{U} / \mathrm{ml}$, respectively, at the time of study $27-30$ days after thyroidectomy.

\section{Discussion}

The present data show that after thyroidectomy the near term ovine fetus rapidly becomes hypothyroid; the serum T4 concentration falls to $<0.7 \mu \mathrm{g} / 100 \mathrm{ml}$; serum T3 levels are unmeasurable $(<18 \mathrm{ng} / 100 \mathrm{ml})$, and serum TSH concentrations increase to 300-1500 $\mu \mathrm{U} / \mathrm{ml}$. Moreover, these low fetal serum iodothyronine values persist in spite of large maternal to fetal gradients of T4 and T3 and a large fetal to maternal gradient of TSH across the placenta. These results are in agreement with data of Hopkins and Thorburn [11], who also reported a rapid fall of fetal serum T4 (from a mean of $11 \mu \mathrm{g} / 100 \mathrm{ml}$ to undetectable levels) after fetal thyroidectomy.

The maternal serum $T 4, T 4 V_{D}$, and $T 4_{s}$ values in the present report (Table II) are significantly greater than those previously reported in our euthyroid ovine 


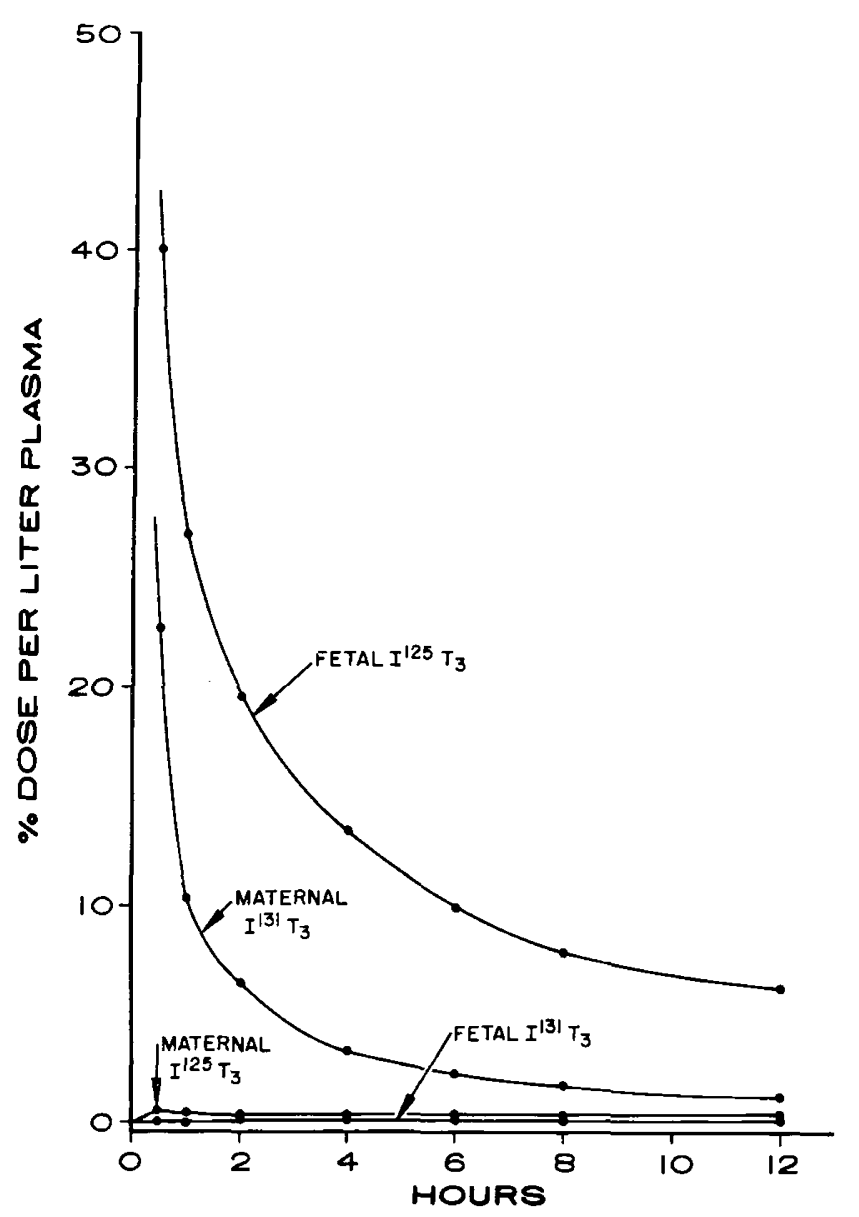

Fig. 6. Arithmetic plots of the disappearance of labeled triiodothyronine $\left(I^{131} T_{3}\right)$ from fetal and maternal sera and the appearance of fetal ${ }^{125}$ I-labeled triiodothyronine $(\mathrm{T} 3)$ in maternal serum and matemal ${ }^{131} \mathrm{I}$-labeled T3 in fetal serum. The data represent mean values for all experiments.

studies [3]. Several factors might account for this. Serum T4 was measured by RIA in the present study rather than the Murphy-Pattee method as in the previous report; T4 RIA results are $15-20 \%$ higher than results using the Murphy-Pattee method, inasmuch as the latter are not corrected for extraction losses. A lower mean environmental temperature and the fact that most of the present sheep had been shorn might be of significance; both factors would tend to increase T4 turnover [9]. In addition, wound infections associated with T4 sequestration might have contributed [10].

In the thyroidectomized fetuses, the $\mathrm{T} 4 \mathrm{~V}_{\mathrm{D}}$ and $\mathrm{T} 4$ $t_{1 / 2}$ values were similar to results reported previously in euthyroid fetuses [3], although the serum T4 values and $T 4_{S}$ were much lower due to fetal thyroidectomy. The mean fetal serum T3 concentrations were $<18$ ng/ $100 \mathrm{ml}$ in both euthyroid and hypothyroid animals, and the mean $\mathrm{T} 3 \mathrm{~V}_{\mathrm{D}}$ values were similar (Reference 4 and Table IV). The mean $T 3 t_{1 / 2}$ value, however, was significantly longer in the hypothyroid fetuses $(10.0 \pm$ $0.3 \mathrm{hr}$ versus $5.5 \pm 0.6 \mathrm{hr}, P<0.001)$ and the mean fractional T3 degradation rate $(k)$ was therefore less ( 1.67 versus $3.9, P<0.01)$. This may be accountable on the basis of relatively unsaturated iodothyroninebinding proteins.

Placental transfer of $\mathrm{T} 3$ and $\mathrm{T} 4$ were estimated as previously described [4]. Mean net T4 transfer approximated $0.6 \mu \mathrm{g} / 24 \mathrm{hr}$ in the maternal to fetal direction, and mean net T3 transfer approximated $0.7 \mu \mathrm{g} / 24 \mathrm{hr}$ in the maternal to fetal direction. These amounts represent less than $0.2 \%$ and about $50 \%$, respectively, of the mean daily $\mathrm{T} 4$ and $\mathrm{T} 3$ turnover rates measured in the euthyroid fetus [3-5]. If a T3/T4 potency ratio of $4 / 1$ is assumed, these values represent only about $7 \%$ of the total T4 equivalent turnover $\left(\mathrm{T} 4_{\mathrm{s}}+4 \times \mathrm{T} 3_{\mathrm{S}}\right)$ in the euthyroid fetuses. The high fetal serum TSH

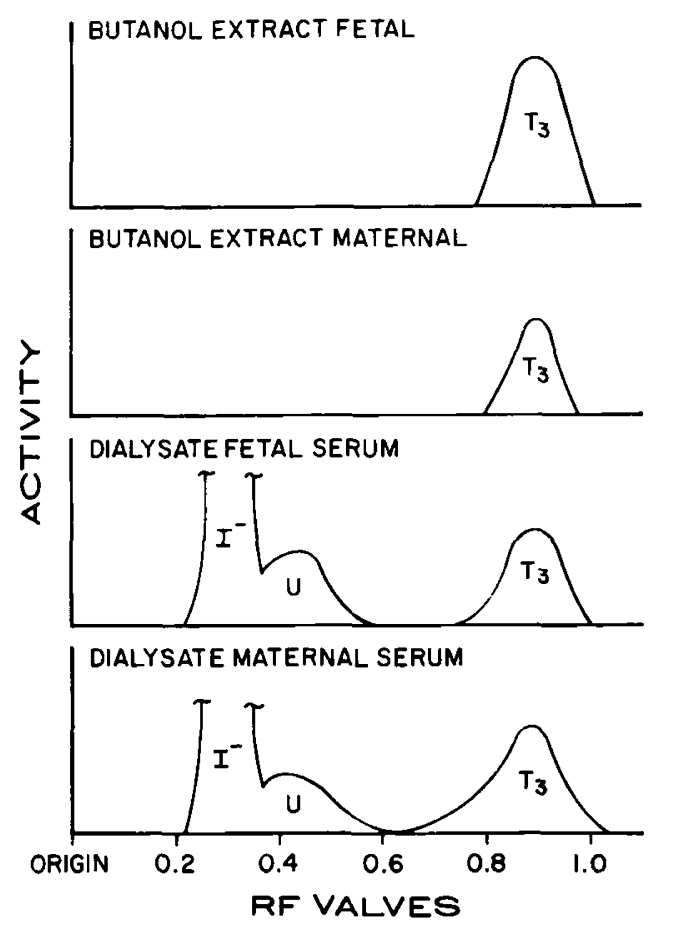

Fig. 7. Drawings of paper chromatograms of fetal and maternal sera $2-4 \mathrm{hr}$ after administration of ${ }^{125} \mathrm{I}$-labeled triiodothyronine $\left(T_{3}\right)$ to the thyroidectomized fetus. The chromatograms were developed in a butanol-acetic acid solvent system. The two upper panels show the triiodothyronine peaks in washed butanol extracts of fetal and maternal sera; the two lower panels show the iodide and unidentified peaks of activity in dialysates of fetal and maternal sera. The vertical axis represents radioactivity and the horizontal axis, $R_{F}$ values. 
values $(300-1500 \mu \mathrm{U} / \mathrm{ml})$ indicate that the thyroidectomized fetuses were, in fact, hypothyroid.

The present data regarding placental transfer of iodothyronines are in general agreement with earlier reports. Dussault et al. [3] found essentially no transfer of labeled T4 across the ovine placenta. Hopkins et al. [11], after injecting $500 \mu \mathrm{g}$ of $\mathrm{T} 4$ into pregnant ewes at 123-146 days of gestational age and approximately 13-36 days after fetal thyroidectomy, found no rise in fetal serum $\mathrm{T} 4$ concentrations even though there was a 4-6 $\mu \mathrm{g} / 100 \mathrm{ml} \mathrm{T} 4$ gradient across the placenta. Robin et al. [12] found a small net bidirectional exchange of labeled $\mathrm{T} 4$ in the last trimester in pregnant sheep, but this was not quantified in terms of unlabeled hormone.

Finally, in maternal and fetal blood after administration of labeled T3, we observed a peak of radioactivity with chromatographic characteristics similar to the $\mathrm{T} 3$ sulfate reported in fetal and maternal blood of monkeys by Schultz et al. [13]. We did not, however, conduct sulfatase hydrolysis of this compound. Because this substance seemed highly polar and did not appear in the aqueous alkali-washed butanol extracts, it did not complicate the kinetic data of this study. The T3 observed during chromatography of fetal serum after injection of radioiodine-labeled $\mathrm{T} 4$ may represent $\mathrm{T} 3$ derived either from artifactual deiodination of thyroxine during TAA paper chromatography or in vivo conversion of $\mathrm{T} 4$ to $\mathrm{T} 3[6,7]$.

\section{Summary}

Fetal thyroidectomy has been performed on fetal sheep in utero between 90 and 125 days of gestational age. After this procedure, the fetus rapidly becomes hypothyroid, as indicated by unmeasurable serum levels of T4 and T3 and very high serum TSH concentrations. Daily fetal $\mathrm{T} 4_{\mathrm{s}}$ and $\mathrm{T} 3_{\mathrm{s}}$ average less than 3.23 and $1.05 \mu \mathrm{g} / \mathrm{kg} / 24 \mathrm{hr}$ as contrasted with values of 41 and $<1.45 \mu \mathrm{g} / \mathrm{kg} / 24 \mathrm{hr}$ in euthyroid fetuses (reported previously). Maternal serum T4 and T3 concentrations remain unchanged so that large maternal to fetal gradients of T4 and T3 exist across the placenta. In spite of this, there is little net transfer of maternal T4 or T3 to the fetus. These results further substantiate the autonomy of the fetal pituitary-thyroid system.

\section{References and Notes}

1. Chopra, I. J:: A radioimmunoassay for measurement of thyroxine in unextracted serum. J. Clin. Endocrinol. Metab., 3t: 938 (1972).

2. Chopra, I. J., Ho, R. S., AND LAM, R.: An improved radioimmunoassay of triiodothyronine in serum: Its application to clinical and physiological studies. J. Lab. Clin. Med., 80: 729 (1972).

3. Dussault, J. H., Hobel, C. J., and Fisher, D. A.: Maternal and fetal thyroxine secretion during pregnancy in the sheep. Endocrinology, $88: 47$ (1971).

4. Dussault, J. H., Hobel, C. J., DiStefano, J. J., III, Erenberg, A., AND FISHER, D. A.: Triiodothyronine turnover in maternal and fetal sheep. Endocrinology, 90: 1301 (1972).

5. Fisher, D. A., Dussault, J. H., Erenberg, A., and Lam, R. W.: Thyroxine and triiodothyronine metabolism in matemal and fetal sheep. Pediat. Res., 12: 894 (1972).

6. Fisher, D. A., ANd Dussault, J. H.: Contribution of methodological artifacts to the measurement of $\mathrm{T} 3$ concentrations in serum. J. Clin. Endocrinol. Metab., 32: 675 (1971).

7. Fisher, D. A., Chopra, I. J., ANo Dussault, J. H.: Extrathyroidal conversion of thyroxine to triiodothyronine in sheep. Endocrinology, 91: 1141, (1972).

8. Fisher, D. A., Morris, M. D., Lehman, H., and Lackey, C.: Studies of the butanol-extractable iodine technique by the ceric oxidation method. Anal. Biochem., 1: 37 (1964).

9. Freinkel, N., ANd Lew'is, D.: The effect of lowered environmental temperature on the peripheral metabolism of labeled thyroxine in the sheep. J. Physiol., 135: 288, (1957).

10. Furch-Rosenberc, H., Hansen, H. J. M., and Moltke, E.: The accumulation of albumin ${ }^{125} \mathrm{I}$ and thyroxine ${ }^{131} \mathrm{I}$ in wounds. Acta Physiol. Scand., 77: 252 (1969).

11. Hopkins, P. S., AND Thorburn, G. D.: Placental permeability to maternal thyroxine in the sheep. J. Endocrinol., 49: 549 (1971).

12. Robin, N., Selenkow, H. A., Fang, V. S., Refetoff, S., Piasecki, G., Rauschecker, H., and Jackson, B. T.: Bidirectional thyroxine exchange in pregnant shecp. Hormones, 3: 235 (1972).

13. Schultz, M. A., Forsander, J. B., Chez, R. A., and HutchinSON, D. L.: The bi-directional placental transfer of $I^{131}-3,5,3^{\prime}$ triiodothyronine in the Rhesus monkey. Pediatrics, 35: 743 (1965).

14. Standard was NIH-TSH-S6.

15. Dr. Erenberg was supported by Postdoctoral Research Fellowship 5-F03-HD 46762 from the National Institute of Child Health and Human Development.

16. This research was supported by United States Public Health Service Grants nos. HD-04270 and HD-4610 from the National Institute of Child Health and Human Development.

17. Requests for reprints should be addressed to: D. A. Fisher, M.D., Department of Pediatrics, Harbor General Hospital, 1000 W. Carson St., Torrance, Calif. 90509 (USA).

18. Accepted for publication June 4, 1973. 